\title{
Temporal Variation in the Biomass, Quantity and Quality of Agar from Gelidiella acerosa (Forsskål) Feldmann et Hamel (Rhodophyta: Gelidiales) from Cape Bolinao, NW Philippines
}

\author{
M. Y. Roleda ${ }^{a, *}$, E. T. Ganzon-Fortes ${ }^{a}$, N. E. Montaño ${ }^{a}$ and F. N. de los Reyes \\ a Marine Science Institute, College of Science, University of the Philippines, P. O. Box 1, Diliman 1101, Quezon City, \\ Philippines \\ b Statistical Center, University of the Philippines, Diliman 1101, Quezon City, Philippines \\ * Corresponding author
}

\begin{abstract}
The monthly changes in the biomass, and yield and gel properties of agar from Gelidiella acerosa were investigated in the intertidal populations from Dos Hermanos, Bolinao for 13 months. Acetic acid pretreatment and steam pressure were employed in agar extraction. The agar isolated was of industrial quality. Highest biomass and agar yield were obtained during the wet season. Biomass peaked in October 1993 (45.14 $\mathrm{g} \mathrm{DW} \mathrm{m}^{-2}$ ) while agar yield was maximum in August 1993 (34\%) and May 1994 (31\%). However, overall gel quality was highest in the dry season (March and April 1994), when gel strength peaked at $800 \mathrm{~g} \mathrm{~cm}^{-2}$ and sulfate content was lowest at $0.4 \%$. An inverse relationship between agar yield and its physical properties (gel strength, viscosity, gelling and melting temperatures) were observed. Dry season low biomass and agar yield were observed to be affected by dessication stress due to frequent emersion of the intertidal flat and the plant's exposure to strong radiation, while high gel strength was associated with the seasonally high intensity water movement (tide-driven surf).
\end{abstract}

\section{Introduction}

Gelidiella acerosa (Forsskål) Feldmann et Hamel is considered an important source of raw material for agar production (Armisen and Galatas 1987), contributing an annual average of 350 dry tons of harvest from India and China to the worldwide commercial agar industry (McHugh 1991). In the Philippines, an estimated 200-300 tons of fresh G. acerosa was reported to be harvested in 1964 (Yamada 1976). Since then, there have been no other published reports on the local production of this resource.

Locally, G. acerosa is exploited for its economic use as food and source of agar (Ganzon-Fortes 1994). Stock assessment of this agarophyte in Mantigue Island, Mindanao, SE Philippines, showed that the standing stock is directly affected by the number of harvesters, which accounts for the localized depletion of the resource (Fortes 1993). It has been established for Gracilaria and Gelidium species that agar content and quality depend on the season of the year (Hoyle 1978, Whyte et al. 1981, Carter and Anderson 1986, Onraët and Robertson 1987, Freile-Pelegrin et al. 1995). According to Santelices (1988), a comprehensive management model based on seasonal changes in the yield and quality of agar should precede intensive harvesting and exploitation of agarophytes where changes in their biochemistry are usually associated with variations in water temperature, light intensity, photoperiod and geography.
Seasonal biomass distribution of $G$. acerosa in Hawaii showed that light intensity and water movement are two important factors that regulate its growth and bleaching in the field (Santelices 1978). On the other hand, in northern Philippines, we have observed that the impact of biological factors such as grazing by fishes and macroinvertebrates seemed to have an insignificant effect to the biomass of $G$. acerosa. The plants have wiry and tough thalli and they are usually found closely associated with other seaweed species such as Mastophora rosea (C. Agardh) Setchell, Laurencia flexilis Setchell, L. papillosa (Forsskål) Greville, L. obtusa (Hudson) Lamouroux, Gracilaria eucheumoides Harvey, Chaetomorpha crassa (C. Agardh) Kützing, Boodlea composita (Harvey) Brand or grow underneath Sargassum species.

Previous studies on various agarophytes have shown that seasonally. in biomass production may or may not have a similar pattern with agar yield and quality. In Onikusa pristoides (Akatsuka [= Gelidium pristoides (Turner) Kützing] from Port Alfred, South Africa, simultaneous peaks in biomass, agar yield and quality (in terms of gel strength, maximum 3,6-AG levels, and minimum $\% \mathrm{SO}_{4}$ content) occurred during the summer months (Onraët and Robertson 1987). A similar relationship between biomass and agar yield was also found for Gracilaria dentata J. Ag. from Ghana, Africa (John and Asare 1975); whereas, an inverse relationship was observed between biomass and agar yield in Gracilaria (verrucosa type) from 
Vancouver, Canada (Whyte et al. 1981). On the other hand, no definite seasonal trend was observed between biomass and agar yield in $G$. bursapastoris (Gmelin) Silva and G. coronopifolia J. Ag. in Hawaii, although in February the lowest agar yield observed for $G$. bursapastoris, coincided with the minimum biomass (Hoyle 1978). In Gelidiella acerosa from India, a preliminary study showed that agar yield and gel strength attained highest levels about a month prior to the peak period of growth (Thomas et al. 1975 a). However, further studies on the same populations have shown that frequent harvesting led to lower production rates with a simultaneous reduction in the content and properties of its agar (Thomas et al. 1975 b 1978). Aside from these studies that looked into the impact of harvesting pressure on $G$. acerosa, no study had been made on the effect of environmental factors on the agar component. This study aims to provide information on the temporal variation in the biomass, quantity and quality of agar from $G$. acerosa in relation to the environmental factors that might have affected these variations.

\section{Materials and Methods}

\section{Biomass determination}

Material was collected monthly (last week of the month) from August 1993 to August 1994 at the reef flat of the northwestern side of Dos Hermanos Island, Bolinao, Pangasinan, Philippines (lat. $16^{\circ} 25.71^{\prime} \mathrm{N}$, long. $119^{\circ} 55.87^{\prime} \mathrm{E}$ ) (Fig. 1). Beds and patches of Gelidiella acerosa abound at between 2 and $10 \mathrm{~m}$ around the perimeter of the island, covering about $300 \mathrm{~m}^{2}$ area. Biomass was measured using a $0.25 \mathrm{~m}^{2}$ quadrat (subdivided into twenty five $10 \times 10$ $\mathrm{cm}$ areas) haphazardly thrown 15 times on the seaweed bed using a permanent transect line laid perpendicular from the shore as reference point. Systematic sampling along the transect was also done per meter. The frequency $(=\mathrm{qn})$ and cover $(=\mathrm{C})$ of $G$. acerosa inside the quadrat were estimated based on the method of Saito and Atobe (1970). The cover value per $100 \mathrm{~cm}^{2}$ area was estimated using indices $(1-5)$ denoting classes of algal dominance: $\mathrm{C}_{5}=50-100 \%$ cover, $\mathrm{C}_{4}=25-50 \%, \mathrm{C}_{3}=12.5-25 \%, \mathrm{C}_{2}=6.25-$ $12.5 \%$ and $\mathrm{C}_{1}=<6.25 \%$ cover. To calculate biomass per quadrat, only a representative sample from one $100 \mathrm{~cm}^{2}$ plot with the highest cover value, was harvested within the $0.25 \mathrm{~m}^{2}$ quadrat. Harvested samples were labelled, brought to the laboratory, cleaned of epiphytes and oven dried at $60^{\circ} \mathrm{C}$ for $36 \mathrm{~h}$ to obtain the dry weight (DW). The biomass per quadrat was then extrapolated using the formula:

Biomass $\left(\mathrm{g} / 0.25 \mathrm{~m}^{2}\right)=$

$\left\{\left[\mathrm{qnC}_{5} \times\right.\right.$ wt $\mathrm{C}_{5}$ (dry weight of harvested plot with $\mathrm{C}_{5}$ relative cover)]

$+\left[\mathrm{qnC}_{4} \times \mathrm{wt} \mathrm{C}_{5} / 2\right]+\left[\mathrm{qnC}_{3} \times \mathrm{wt} \mathrm{C}_{5} / 4\right]$

$+\left[\mathrm{qnC}_{2} \times\right.$ wt $\left.\left.\mathrm{C}_{5} / 8\right]+\left[\mathrm{qnC}_{1} \times \mathrm{wt} \mathrm{C}_{5} / 16\right]\right\}$

qn: $\quad$ number of $10 \times 10 \mathrm{~cm}$ areas in which the species appeared.

$\mathrm{C}_{1}, \mathrm{C}_{2}, \ldots \mathrm{C}_{5}$ : over value denoting each class of algal dominance.

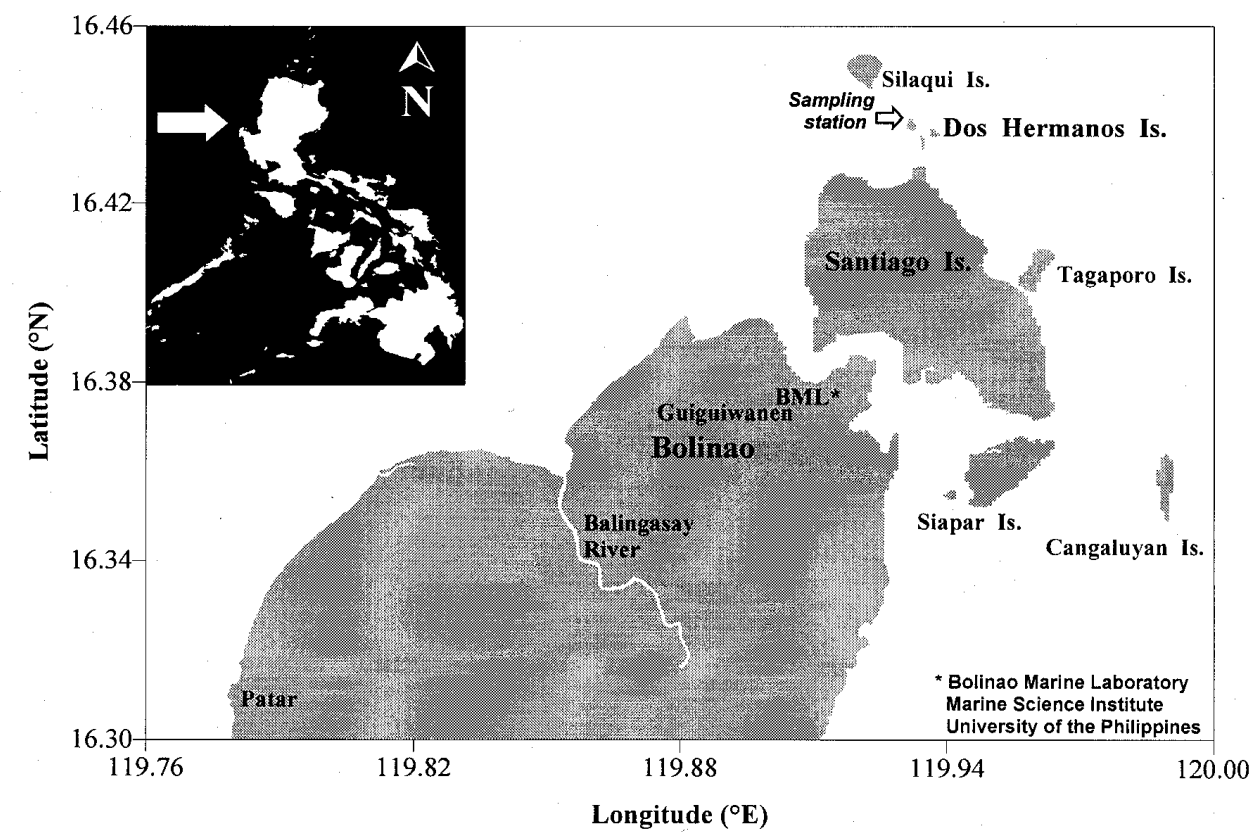

Fig. 1. Sampling station in the northwestern reef flat of Dos Hermanos, Bolinao, Pangasinan (Inset: map of the Philippines). 
This was done to avoid depletion of natural stock in the area and minimize the impact of our own sampling that could potentially affect the succeeding month's biomass measurement.

\section{Agar extraction and analyse of agar properties}

For agar extraction, approximately $2 \mathrm{~kg}$ wet weight of plants were collected haphazardly by hand within the northwestern side of the reef flat. These were cleaned of epiphytes, washed with tap water and airdried. Dried samples of $30 \mathrm{~g}$ (in duplicate) each were pretreated with acetic acid and steam pressure extraction was employed to isolate agar (Roleda et al. 1997), using a portable $20 \mathrm{~L}$ pressure cooker heated by an electric stove. The agar was dried in an oven at $60^{\circ} \mathrm{C}$ and percentage yield was calculated from the dry weight of the original sample (raw material).

Gel strength $\left(\mathrm{g} \mathrm{cm}^{-2}\right)$ was measured on $1.5 \%$ agar solution previously cured overnight. The gel was slowly displaced and removed from the beaker, then replaced inverted into the same vessel to test the bottom surface of the gel (Roleda et al. 1997). Relative viscosity of a $1.0 \%$ solution at $65^{\circ} \mathrm{C}$ expressed in centipoise (cps), and the gelling and melting temperatures from the $1.0 \%$ agar stock solution were determined as described in Whyte and Englar (1980). Percent sulfate content was determined using the turbidometric method (Jackson and McCandless 1978). For every $2.2 \mathrm{~mL}$ agar sample solution (made from $20 \mathrm{mg}$ agar sample hydrolized in $10 \mathrm{~mL} 1 \mathrm{~N} \mathrm{HCl}$, mixed with $25 \mathrm{~mL} 10 \% \mathrm{H}_{2} \mathrm{O}_{2}$ and diluted to $100 \mathrm{~mL}$ with distilled water) and sulfate solutions (6 different concentrations diluted from the standard solution of $100 \mathrm{mg} \mathrm{SO} / \mathrm{L}$ ), $2.4 \mathrm{~mL}$ of $8 \%$ trichloroacetic acid (TCA) and $1.2 \mathrm{~mL}$ of $0.01 \%$ agarose reagent were added, mixed with a vortex mixer and left to stand for 35 minutes. Absorbance was read at $500 \mathrm{~nm}$ and percent sulfate was determined based on the standard curve for sulfate concentration. For percent 3,6anhydrogalactose $(3,6-\mathrm{AG})$ content, $10 \mathrm{mg}$ agar sample was hydrolized in $15 \mathrm{~mL}$ distilled water until the agar was completely dissolved. Water lost due to evaporation was replenished. Then $0.1 \mathrm{~mL}$ agar solution was transferred into a test tube and diluted with distilled water to $2 \mathrm{~mL}$. The test tube was cooled in an ice bath and $10 \mathrm{~mL}$ of resorcinol-acetal reagent was added, then mixed thoroughly using a test tube vibrator. The loosely capped tube was warmed at $20^{\circ} \mathrm{C}$ for $4 \mathrm{~min}$ and then heated at $80^{\circ} \mathrm{C}$ for $10 \mathrm{~min}$. The tube was cooled again in an ice bath for $1.5 \mathrm{~min}$ and absorbance was read at $555 \mathrm{~nm}$ within $15 \mathrm{~min}$. The quantity of 3,6-AG was determined by reference to the standard curve for fructose (Craigie and Leigh 1978). All analyses were done in triplicate.

\section{Environmental factors}

Relative water movement at the collecting site (diffusion factor, DF) was measured using the clod-card method of Doty (1971). Salinity was measured with an AO T/C Refractometer while minimum and maximum water temperatures were measured with a Taylor $\min / \max$ thermometer. Monthly total number of days with extreme low tides resulting in the emersion of the intertidal flat was calculated from the tide table provided by the Bureau of Coast and Geodetic Survey (BCGS). Data of the total monthly rainfall, mean air temperature, humidity, and total radiation were obtained from the nearest station of the Philippine Atmospheric Geophysical and Astronomical Services (PAGASA) located in Dagupan City, Pangasinan (lat. $16^{\circ} 03^{\prime} \mathrm{N}$ long., $120^{\circ} 20^{\prime} \mathrm{E}$ ). Mean values of the environmental parameters measured prior to the sampling period were used in the statistical analysis.

\section{Statistical analysis}

Data for biomass, agar yield and properties were tested for normality (Shapiro-Wilks Statistics). Corresponding transformations were done to non-normal data. Multiple regression analysis was rejected because the assumption of independence of each predictor variables (environmental factors) was not satisfied. Consequently, Principal Component Analysis (PCA) was performed to reduce the 8 environmental factors into a new set of variables (environmental principal component, ENVIPC) that is a linear additive function of the old variables. The first new variable extracted (e.g. ENVIPC1) is the linear additive function which accounts for the largest possible amount of variation in the data (environmental factors). Each additional new variable (e.g. ENVIPC2, ENVIPC3 ...) accounts for the largest possible amount of remaining variation, independent of (= orthogonal to) the previously derived principal component. Therefore, the new variable will be uncorrelated (= independent), unlike the original variables (environmental factors) (Green 1979). Each of the resulting environmental principal component (ENVIPC) still contained all the information of the 8 variables but are represented by two or more environmental factors as primary indicators. Subsequenlty, the statistical significant differences of the dependent variables: biomass, agar yield and gel properties (gel strength, viscosity, melting and gelling temperatures, percent sulfate and 3,6-anhydrogalactose) as affected by the environmental factors were tested using Analysis of Covariance (ANACOVA $\mathrm{p}=0.05$ ) using the model:

$y=f($ categorical variable $)+f($ continuous variables)

where date is the categorical variable to determine time effect (temporal variation) and the ENVIPCs are the continuous variables. This was followed by Duncan's Multiple Range Test (DMRT, $p=0.05$ ). Simple correlation analysis was used to correlate the relationship between biomass and agar yield, agar yield and gel properties, and between gel properties. Statistical analyses were done using SAS program. 


\section{Results}

Monthly variations in the biomass, agar yield and physical and chemical properties of the gel are shown in Figure 2. Biomass was highest in October 1993 (45.14 $\left.\mathrm{g} \mathrm{DW} \mathrm{m}^{-2}\right)$ and lowest in June $1994(10.37 \mathrm{~g}$ DW $\mathrm{m}^{-2}$ ), when bleaching of Gelidiella acerosa was observed. A peak and trough in biomass were observed during the wet and dry seasons. However, relatively high biomass was observed during the wet months (May-October, mean $=16 \pm 1 \mathrm{~g} \mathrm{DW} \mathrm{m}^{-2}$ ) compared to the dry months (November-April, mean $=22 \pm 6 \mathrm{~g} \mathrm{DW} \mathrm{m}^{-2}$ ). High agar yields were measured from plants harvested during the wet months of August 1993 (34\%), May (31\%), July (30.15\%) and August 1994 (26.8\%); however, relatively low agar yields were also measured during the wet months of September $1993(21.9 \%)$ and June $1994(21.7 \%)$, and lowest during the dry month of February 1994 (19.7\%).

A progressive increase in agar gel strength was observed from December $1993\left(371 \mathrm{~g} \mathrm{~cm}^{-2}\right)$ and peaked in April $1994\left(800 \mathrm{~g} \mathrm{~cm}^{-2}\right)$. However, high gel strength was also observed during the wet season months of June $\left(616 \mathrm{~g} \mathrm{~cm}^{-2}\right)$ and August $1994(701 \mathrm{~g}$ $\mathrm{cm}^{-2}$ ) but this was lower than the observed dry season peak. Lowest gel strength was recorded in August $1993\left(360 \mathrm{~g} \mathrm{~cm}^{-2}\right)$. Relative viscosity at $65^{\circ} \mathrm{C}$ ranged from 5 to $70 \mathrm{cps}$. Gelling temperature ranged from 42 to $47^{\circ} \mathrm{C}$, while melting temperature ranged from 90 to $98{ }^{\circ} \mathrm{C}$. Sulfate content varied from $0.4 \%$ to $2.1 \%$ while 3,6-anhydrogalactose varied from $39.2 \%$ to $44.2 \%$.

Monthly variations in the environmental factors are shown in Figure 3. Bolinao has a rainfall pattern marked by the presence of two pronounced seasons, wet from May to October and dry the rest of the year. Total monthly rainfall during the wet months ranges from 130.4 to $908.8 \mathrm{~mm}$. November is a transition period with a relatively higher rainfall (total $=86.3 \mathrm{~mm}$ ) compared to the rest of the dry months (range $=1.0-25.2 \mathrm{~mm}$ ). March has the lowest rainfall, humidity and water temperature. Air temperature during the dry months ranges from 25.9 to $29.6^{\circ} \mathrm{C}$ while wet months ranges from 27.4 to $29.8^{\circ} \mathrm{C}$. December is the coldest while May is the warmest months. Radiation during the dry and wet season ranges from $27.5-36.4$ and $20.5-36.2 \mathrm{E} \mathrm{m}^{-2}$ day $^{-1}$ respectively. Higher salinity was observed during the dry months (mean $=33 \pm 0.7 \%$ ) compared to the wet months (mean $=31 \pm 1.2 \%$ ). Moreover, during the dry months of November to April, the intertidal flat was frequently exposed due to extreme low tides (days with emersion $=8-28$ ) and subjected to relatively strong water movement due to tidedriven surf (DF $=4.78-10.61)$ compared to the wet months with minimum exposure (days with emersion $=2-5)$ and lower intensity of water movement (DF $=2.01-4.73$ ).
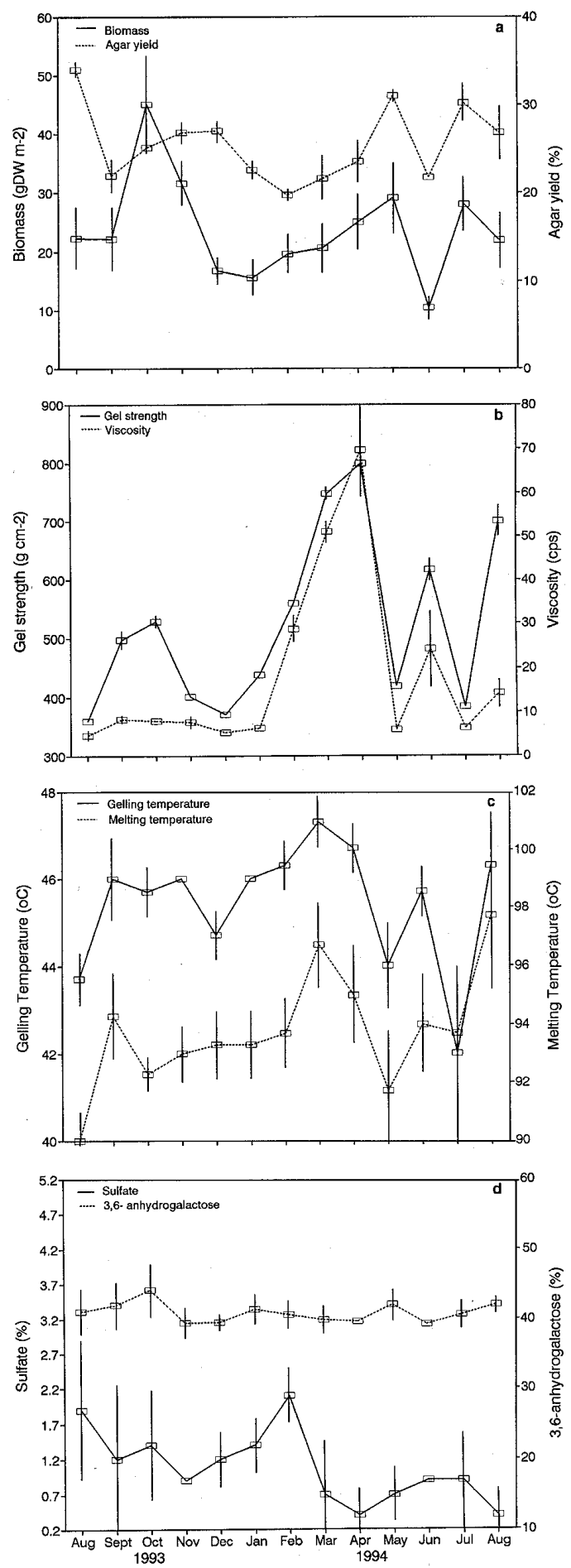

Fig. 2. Monthly variations of the biomass and agar yield (a), gel strength and viscosity (b), melting and gelling temperatures (c), \% sulfate and 3,6-anhydrogalactose contents (d) of Gelidiella acerosa. Bars indicate standard deviation. 

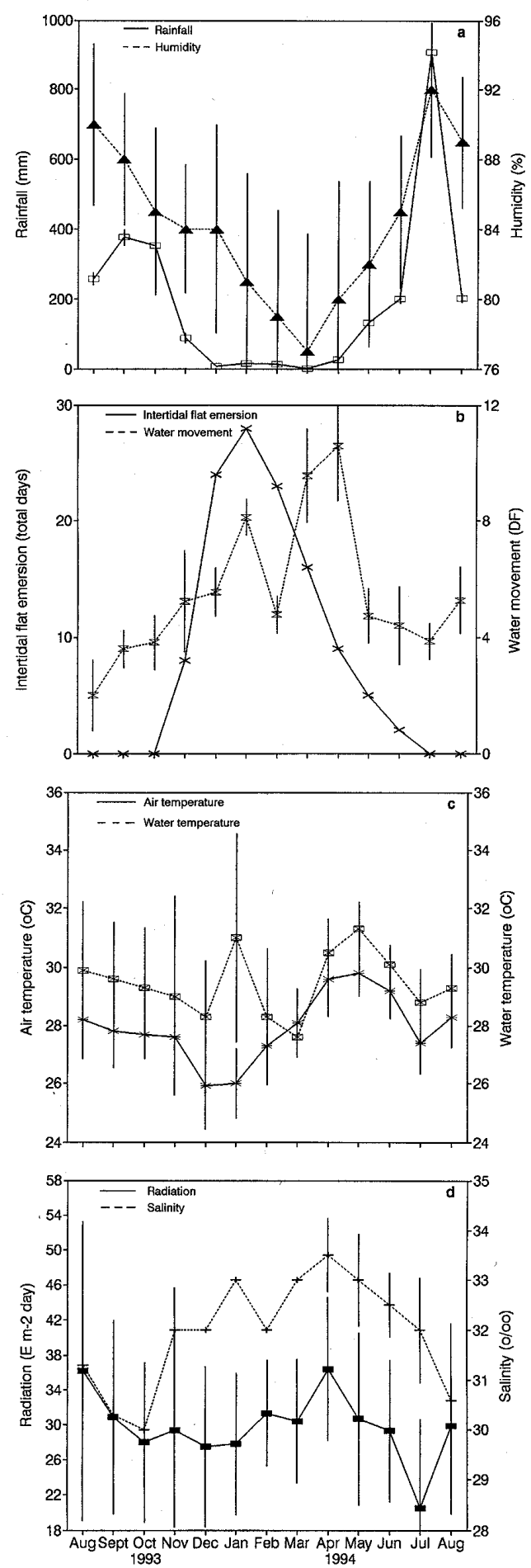

Fig. 3. Monthly variations in the environmental factors. Variables in (a) and (b) represent the major indicators of ENVIPC1, (c) ENVIPC2 and (d) ENVIPC3, Bars indicate standard deviation.
Principal component analysis (PCA) resulted into grouping of the environmental factors into three aggregate components designated as ENVIPC1, ENVIPC2 and ENVIPC3, where the correlation matrix represents $82.75 \%$ of the total variance. The synergy between days with extreme low tide (intertidal flat emersion), water movement, rainfall and humidity were the major indicators of ENVIPC1 (with principal component, PC loading values of $0.412,0.421$, -0.454 and -0.483 respectively). This association was distinctly observed between the two prevailing seasons, where frequent emersion of the tidal flat, stronger water movement (tide-driven surf), minimum monthly rainfall and lower humidity $(77-84 \%)$ were observed during the dry months as opposed to the wet months where minimal exposure occurred during May and June, and total immersion of the intertidal flat during the rest of the wet months, coupled with low intensity water movement, maximum rainfall and high humidity $(82-92 \%)$. The functional interaction between air and water temperatures were the major factors in ENVIPC2 (with PC loading values of 0.679 and 0.54 respectively), while the major indicators of ENVIPC3 were salinity and radiation (with PC loading values of 0.524 and -0.692 respectively).

Analysis of covariance (Table I) showed significant temporal variation in the mean monthly biomass (LNBiomass, $p=0.0001$ ), yield (LNYield, $p=$ $0.0002)$, gel strength $(\mathrm{p}=0.0001)$, viscosity $(\mathrm{p}=$ $0.0001)$, gelling temperature $(\mathrm{p}=0.0004)$ and melting temperature $(p=0.0002)$. All ENVIPCs were found to vary significantly with biomass, while ENVIPIC1 and ENVIPC2 were found to vary significantly with agar yield and gel strength. Monthly significant/insignificant differences (DMRT, $p=0.05$ ) showed that biomass production was significantly high in October 1993, while biomass in November 1993, April, May and July 1994 were not significantly different. The decreasing order of monthly agar yields were as follows: August 1993, May and July $>$ November and December, and August $1994>$ October and April > September, March and June $>$ January and February. The top 5 months with the highest gel strength measured were: April > March > August $1994>$ June $>$ February. The relative viscosity, gelling and melting temperatures of agar were observed to follow a similar pattern to gel strength. Low sulfate and high 3,6-AG contents were measured which did not significantly vary through time. Correlation analysis between the biomass, physical and chemical properties of agar are shown in Table II.

\section{Discussion}

The low biomass measured during the dry months (December to March) was observed to be affected by the frequent emersion of the intertidal flat (16-28 times) coupled with exposure to strong sunlight. At 
Table I. Analysis of covariance and significance values for seasonality in biomass, agar yield, and gel properties (LN is transformation to the natural logarithm).

\begin{tabular}{|c|c|c|c|c|c|}
\hline \multirow[t]{2}{*}{ Dependent variable } & \multicolumn{2}{|l|}{ Independent } & \multirow[t]{2}{*}{$\mathrm{DF}$} & \multirow[t]{2}{*}{ F-value } & \multirow[t]{2}{*}{ p-value } \\
\hline & $\begin{array}{l}\text { categorical } \\
\text { variable }\end{array}$ & $\begin{array}{l}\text { continuous } \\
\text { variables }\end{array}$ & & & \\
\hline LN Biomass (mean) & Date & $\begin{array}{l}\text { ENVIPC1 } \\
\text { ENVIPC2 } \\
\text { ENVIPC3 }\end{array}$ & $\begin{array}{l}9 \\
1 \\
1 \\
1\end{array}$ & $\begin{array}{l}99999.99 \\
99999.99 \\
99999.99 \\
99999.99\end{array}$ & $\begin{array}{l}0.0001^{*} \\
0.0001^{*} \\
0.0001^{*} \\
0.0001^{*}\end{array}$ \\
\hline LN Yield & Date & $\begin{array}{l}\text { ENVIPC1 } \\
\text { ENVIPC2 } \\
\text { ENVIPC3 }\end{array}$ & $\begin{array}{l}9 \\
1 \\
1 \\
1\end{array}$ & $\begin{array}{r}9.42 \\
29.04 \\
4.92 \\
0.33\end{array}$ & $\begin{array}{l}0.0002^{*} \\
0.0001^{*} \\
0.0449^{*} \\
0.5731 \mathrm{~ns}\end{array}$ \\
\hline Gel strength & Date & $\begin{array}{l}\text { ENVIPC1 } \\
\text { ENVIPC2 } \\
\text { ENVIPC3 }\end{array}$ & $\begin{array}{l}9 \\
1 \\
1 \\
1\end{array}$ & $\begin{array}{r}206.68 \\
384.38 \\
250.87 \\
0.85\end{array}$ & $\begin{array}{l}0.0001^{*} \\
0.0001^{*} \\
0.0001^{*} \\
0.3663 \mathrm{~ns}\end{array}$ \\
\hline Viscosity & Date & $\begin{array}{l}\text { ENVIPC1 } \\
\text { ENVIPC2 } \\
\text { ENVIPC3 }\end{array}$ & $\begin{array}{l}9 \\
1 \\
1 \\
1\end{array}$ & $\begin{array}{r}50.05 \\
298.60 \\
76.56 \\
13.49\end{array}$ & $\begin{array}{l}0.0001^{*} \\
0.0001^{*} \\
0.0001^{*} \\
0.0011^{*}\end{array}$ \\
\hline Gelling temperature & Date & $\begin{array}{l}\text { ENVIPC1 } \\
\text { ENVIPC2 } \\
\text { ENVIPC3 }\end{array}$ & $\begin{array}{l}9 \\
1 \\
1 \\
1\end{array}$ & $\begin{array}{r}5.33 \\
40.27 \\
0.09 \\
14.04\end{array}$ & $\begin{array}{l}0.0004^{*} \\
0.0001^{*} \\
0.7609 \mathrm{~ns} \\
0.0009^{*}\end{array}$ \\
\hline Melting temperature & Date & $\begin{array}{l}\text { ENVIPC1 } \\
\text { ENVIPC2 } \\
\text { ENVIPC3 }\end{array}$ & $\begin{array}{l}9 \\
1 \\
1 \\
1\end{array}$ & $\begin{array}{l}5.77 \\
2.53 \\
0.95 \\
2.05\end{array}$ & $\begin{array}{l}0.0002^{*} \\
0.1236 \mathrm{~ns} \\
0.3384 \mathrm{~ns} \\
0.1122 \mathrm{~ns}\end{array}$ \\
\hline sulfate & Date & $\begin{array}{l}\text { ENVIPC1 } \\
\text { ENVIPC2 } \\
\text { ENVIPC3 }\end{array}$ & $\begin{array}{l}9 \\
1 \\
1 \\
1\end{array}$ & $\begin{array}{l}1.59 \\
0.08 \\
3.78 \\
5.21\end{array}$ & $\begin{array}{l}0.1688 \mathrm{~ns} \\
0.7744 \mathrm{~ns} \\
0.0627 \mathrm{~ns} \\
0.0309^{*}\end{array}$ \\
\hline 3,6-AG & Date & $\begin{array}{l}\text { ENVIPC1 } \\
\text { ENVIPC2 } \\
\text { ENVIPC3 }\end{array}$ & $\begin{array}{l}9 \\
1 \\
1 \\
1\end{array}$ & $\begin{array}{l}1.17 \\
2.43 \\
0.09 \\
0.78\end{array}$ & $\begin{array}{l}0.3558 \mathrm{~ns} \\
0.1308 \mathrm{~ns} \\
0.7636 \mathrm{~ns} \\
0.3856 \mathrm{~ns}\end{array}$ \\
\hline
\end{tabular}

Environmental factors grouped as principal components: ENVIPC1, ENVIPC2 and ENVIPC3 (p-values with * are significant, ns are not significant).

this time of the year, the plants' differential survival capability could have been affected by such detrimental stress as observed in the seasonal disappearance of the majority of the species and reduced frequency of occurrence of the resilient species in the intertidal algal community in Hong Kong (Hodgkiss 1984). The perennial occurrence of the intertidal population of Gelidiella acerosa demonstrates its desiccation-tolerance, which could be attributed to the presence of the agar polysaccharide in its cell wall that helps reduce desiccation stress (Percival and McDowell 1967). In the month of June, bleaching of $G$. acerose thalli was observed and the lowest biomass was measured. This bleaching incident was found to be associated with the highest air and water temperatures re- corded in three consecutive months (April to June, at $29.2-29.8^{\circ} \mathrm{C}$ and $30.1-31.3^{\circ} \mathrm{C}$ respectively), coupled with relatively strong radiation and high salinity. Nitrogen deficiency due to active metabolism of this element induced by high water temperature and brighter sunlight had been reported to cause bleaching of seaweeds (Yamada and Iwahashi 1964).

The high agar yield obtained during the wet season in Gelidiella acerosa differed from the observed simultaneous peak in biomass and agar yield reported for Gelidium pristoides during summer in South Africa (Carter and Anderson 1986, Onraët and Robertson 1987 as Onikusa pristoides). Other studies from temperate regions also reported high agar yield during summer months for Gelidium canariensis (Grunow) 
Table II. Correlation coefficients and probability values in- parenthesis between biomass, agar yield and properties of Gelidiella acerosa.

\begin{tabular}{|c|c|c|c|c|c|c|c|}
\hline & Agar yield & Gel strength & Viscosity & Gelting temp. & Melting temp. & $\% \operatorname{SO} \$$ & $\% 3,6-\mathrm{AG}$ \\
\hline Biomass & $\begin{array}{l}0.318^{*} \\
(0.048)\end{array}$ & $\begin{array}{c}-0.130 \\
(0.430)\end{array}$ & $\begin{array}{c}-0.163 \\
(0.320)\end{array}$ & $\begin{array}{l}-0.140 \\
(0.396)\end{array}$ & $\begin{array}{l}-0.220 \\
(0.178)\end{array}$ & $\begin{array}{l}-0.034 \\
(0.837)\end{array}$ & $\begin{array}{l}0.357^{*} \\
(0.026)\end{array}$ \\
\hline Agar yield & & $\begin{array}{l}-0.568^{*} \\
(0.0002)\end{array}$ & $\begin{array}{l}-0.487^{*} \\
(0.001)\end{array}$ & $\begin{array}{l}-0.694 * \\
(0.0001)\end{array}$ & $\begin{array}{l}-0.447^{*} \\
(0.004)\end{array}$ & $\begin{array}{c}-0.027 \\
(0.871)\end{array}$ & $\begin{array}{l}0.093 \\
(0.572)\end{array}$ \\
\hline Gel strength & & & $\begin{array}{l}0.846^{*} \\
(0.0001)\end{array}$ & $\begin{array}{l}0.641^{*} \\
(0.0001)\end{array}$ & $\begin{array}{l}0.634^{*} \\
(0.0001)\end{array}$ & $\begin{array}{l}-0.328^{*} \\
(0.041)\end{array}$ & $\begin{array}{c}-0.063 \\
(0.705)\end{array}$ \\
\hline Viscosity & & & & $\begin{array}{l}0.529^{*} \\
(0.0005)\end{array}$ & $\begin{array}{l}0.410^{*} \\
(0.01)\end{array}$ & $\begin{array}{l}-0.254 \\
(0.119)\end{array}$ & $\begin{array}{c}-0.249 \\
(0.127)\end{array}$ \\
\hline Gelling temp. & & & & & $\begin{array}{l}0.465^{*} \\
(0.003)\end{array}$ & $\begin{array}{l}-0.043 \\
(0.793)\end{array}$ & $\begin{array}{l}0.118 \\
(0.474)\end{array}$ \\
\hline Melting temp. & & & & & & $\begin{array}{c}-0.308 \\
(0.057)\end{array}$ & $\begin{array}{c}-0.078 \\
(0.637)\end{array}$ \\
\hline$\% \mathrm{SO} 4$ & & & & & & & $\begin{array}{l}0.266 \\
(0.102)\end{array}$ \\
\hline
\end{tabular}

( $\mathrm{r}$ values with * are significant)

Seoane-Camba from Spain (Freile-Pelegrin et al. 1995) and for G. latifolium (Greville) Thuret et Bornet from France (Mouradi-Givernaud et al. 1992). The above observation is related to the development of a thermocline effecting the lowest nutrient concentration of the year and resulting in low thallus nitrogen content (Hoyle 1978, DeBoer 1979, Bird et al. 1981, Carter and Anderson 1986). In this study, the high agar yield-nitrogen deficiency relationship was insignificant because higher agar yields were observed during the wet season (mean $=27.2 \pm 4.7$ ) when inflow of inorganic nitrogen from land run-off and ground water outflow is suppose to contribute nutrients to the macrophytes during the rainy season (Valiela 1984). On the other hand, tissue nutrient contents of Gelidiella acerosa (Roleda, unpublished data) showed insignificant difference in $\% \mathrm{~N}$ during the wet and dry season $(1.70 \pm 0.2$ and $1.68 \pm 0.3$ respectively) while relatively lower $\% \mathrm{P}$ was measured during the wet $(0.05 \pm 0.01)$ compared to the dry season $(0.07 \pm 0.02)$. These values concurred with the observation of Lapointe et al. (1992) that thallus nutrient content of tropical macrophytes is significantly depleted in phosphorous relative to nitrogen. The lower agar yields (mean $=23.5 \pm 2.9$ ) obtained during the dry months were attributed to desiccation stress due to the periodic exposure of plants to air during emersion of the intertidal flat which probably led to the inhibition of agar production. The effect of this stress was quantified in Gelidium coulteri Harvey by looking into the flow of photosynthate to various end products (Macler 1988). He observed that the partitioning of ${ }^{14} \mathrm{C}$ photosynthate of air-exposed plants, showed increased levels of ${ }^{14} \mathrm{C}$ label in floridoside, a decrease in agar labelling, and up to sixfold increases in total amino acids.
Agar, a heterogeneous polysaccharide that forms the basic structural unit of the cell wall is known to be largely responsible for the mechanical strength of the tissue (Percival and McDowell 1967). The effect of water movement (an indicator of ENVIPC1) on agar gel strength concurred with the observation of Rees and Conway (1962) that, in some seaweed species, stiffer gels are present in plants exposed to more severe wave action. The negative correlation between agar yield and gel strength was related to the the plant's physiological mechanism of undergoing fewer cell division, lowering agar biosynthesis, and forming a cell wall strengthening mechanism. Lahaye and Rochas (1991) described this mechanism where the cell wall thickens to act as a flexible but resistant skeleton, and in vitro substitution of agar polysaccharide with chemical groups and/or formation of cross-links to increase cohesiveness and rigidity of the 'secondarized' cell-wall. The biological function of this mechanism is thought to be for increasing resistance toward pathogens.

Monthly variation in viscosity, melting and gelling temperatures had been observed to be relative to the increase and decrease in gel strength. The monthly low sulfate and high 3,6-anhydrogalactose content further indicated a good quality agar synthesized by Gelidiella acerosa. The insignificant correlation between percent sulfate and 3,6-anhydrogalactose in $G$. acerosa was attributed to the possible occurrence of other sulfate groups on the 3-linked galactose residues which was not the biological precursor of 3,6anhydrogalactose and did not undergo the same enzymatic conversion as that of the L-galactose 6-sulfate residue (Wong and Craigie 1978, Craigie 1990). A similar observation was reported for Gracilaria tikvahiae McLachlan, although its sulfate content 
was high in summer and autumn (Asare 1980). On the other hand, a negative correlation was observed between sulfate and 3,6-anhydrogalactose content in Onikusa pristoides (Onraët and Robertson 1987).

Based on the results of this study, an annual harvesting is recommended for Gelidiella acerosa to minimize the effect of harvesting pressure and compromise maximum available raw material with optimum agar yield and quality. The best period for harvesting is during the dry season month of April, when the biomass is optimum, agar extractable from the plants is of the average quantity, and gel qualities (gel strength, viscosity, gelling and melting temperatures, \% SO4 and 3,6-AG) are characteristically high. Further study on the seasonal occurrence and abundance of tetrasporic plants is recommended to determine the impact of harvesting on the recruitment and biomass production. A concurrent study on agar yield and properties of the different life stages is also encouraged.

\section{References}

Armisen, R. and F. Galatas. 1987. Production, properties and uses of agar. In: (D. J. McHugh, ed.) Production and Utilization of Products from Commercial Seaweeds. FAO Fish. Tech. Pap. 288: 1-57.

Asare, S. O. 1980. Seasonal changes in sulphate and 3,6anhydrogalactose content of phycocolloids from two red algae. Bot. Mar. 23: 595-598.

Bird, K. T., M. D. Hanisak and J. H. Ryther. 1981. Chemical quality and production of agars extracted from $\mathrm{Grac}$ ilaria tikvahiae grown in different nitrogen enrichment conditions. Bot. Mar. 24: 441-444.

Carter, A. R. and R. J. Anderson. 1986. Seasonal growth and agar contents in Gelidium pristoides (Gelidiales, Rhodophyta) from Port Alfred, South Africa. Bot. Mar. 29: $117-123$.

Craigie, J. S. 1990. Cell walls. In: (K. M. Cole and R. G. Sheath, eds) Biology of the Red Algae. Cambridge University Press, Cambridge. pp. 221-257.

Craigie, J. S. and C. Leigh. 1978. Carrageenans and agars. In: (J. A. Hellebust and J. S. Craigie, eds) A Handbook of Phycological Methods - Physiological and Biochemical Methods. Cambridge University Press, New York. pp. $109-132$.

DeBoer, J. A. 1979. Effects of nitrogen enrichment on growth rates and phycocolloid content in Gracilaria foliifera and Neoagardhiella baileyi (Florideophyceae). Proc. Int. Seaweed Symp. 9: 263-273.

Doty, M. S. 1971. Measurement of water movement in reference to benthic algal growth. Bot. Mar. 14: 32-35.

Fortes, M. D. 1993. Assessment of the natural stocks of Gelidiella acerosa (Forssk.) Feld. et Hamel in Mantigue Is., Camiguin, Southern Philippines. In: $($ H. P. Calumpong and E. G. Meñez, eds) Proc. 2nd RP-USA Phycological Symposium/Workshop. Philippine Council for Aquatic and Marine Research and Development (PCAMRD) Los Baños, Laguna. pp. 247-256.

Freile-Pelegrin, Y., D. R. Robledo and G. Garcia-Reina. 1995. Seasonal agar yield and quality in Gelidium canari-

\section{Acknowledgements}

This study was supported by the scholarship grant of the National Committee on Marine Sciences (NCMS), UNESCO National Commission of the Philippines to Michael Y. Roleda. Financial support was provided by the Philippine Council for Aquatic and Marine Research and Development through the Marine Science Institute. We appreciate the assistance of Nell Oca, Cynthia Pagba and Erlinda Encisa for the field work, chemical analyses and the graphics respectively. Our sincerest thanks to Dr S. S. MingoaLicuanan and Rene Rollon for contributing some environmental data. This paper represents contribution number 271 from the Marine Science Institute, University of the Philippines.

Accepted 26 July 1997

ensis (Grunow) Seoane-Camba (Gelidiales, Rhodophyta) from Gran Canaria, Spain. J. Appl. Phycol. 7: $141-144$.

Ganzon-Fortes, E. T. 1994. Gelidiella. In: (I. Akatsuka, ed.) Biology of Economic Seaweeds. SPB Academic Publishing, The Hague, The Netherlands. pp. 149-184.

Green, R. H. 1979. Sampling Design and Statistical Methods for Environmental Biologist. J. Wiley and Sons, New York. $257 \mathrm{pp}$.

Hoyle, M. D. 1978. Agar studies in two Gracilaria species (G. bursapastoris (Gmelin) Silva and G. coronopifolia J. Ag.) from Hawaii. II. Seasonal aspects. Bot. Mar. 21 : $347-352$.

Hodgkiss, I. J. 1984. Seasonal patterns of intertidal algal distribution in Hong Kong. Asian Marine Biology 1: $49-57$.

Jackson, S. G. and E. L. McCandless. 1978. A simple, rapid, turbidometric determination of inorganic sulfate and/or protein. Anal. Biochem. 90: 802-808.

John, D. M. and S. O. Asare. 1975. A preliminary study of the variations in yield and properties of phycocolloids from Ghanian seaweeds. Mar. Biol. 30: 325-330.

Lahaye, M. and C. Rochas. 1991. Chemical structure and physico-chemical properties of agar. Hydrobiologia 221: $137-148$.

Lapointe, B. E., M. M. Littler and D. S. Littler. 1992. Nutrient availability to marine macroalgae in siliciclastic versus carbonate-rich coastal waters. Estuaries 15 $75-82$.

Macler, B. A. 1988. Salinity effects on photosynthesis, carbon allocation, and nitrogen assimilation in the red alga, Gelidium coulteri. Plant Physiol. 88: 690-694.

McHugh, D. J. 1991. Worldwide distribution of commercial resources of seaweeds including Gelidium. Hydrobiologia 221: $12-29$.

Mouradi-Givernaud, A., T. Givernaud, H. Morvan, J. Cosson. 1992. Agar from Gelidium latifolium (Rhodo- 
phyceae, Gelidiales): Bio-chemical composition and seasonal variations. Bot. Mar. 35: 153-159.

Onraët, A. A. and B. L. Robertson. 1987. Seasonal yield and properties of agar from sporophytic and gametophytic phases of Onikusa pristoides (Turner) Akatsuka (Gelidiaceae, Rhodophyta). Bot. Mar. 30: 491-495.

Percival, E. and R. H. McDowell. 1967. Chemistry and Enzymology of Marine Algal Polysaccharide. Academic Press, London-New York. 219 pp.

Rees, D. A. and E. Conway. 1962. The structure and biosynthesis of porphyran: a comparison of some samples. Biochem. J. 84: 411-416.

Roleda, M. Y., N. E. Montaño, E. T. Ganzon-Fortes and R. D. Villanueva. 1997. Acetic acid pretreatment in agar extraction of Philippine Gelidiella acerosa (Forsskaal) Feldmann et Hamel (Rhodophyta, Gelidiales). Bot. Mar. 40: 63-69.

Saito, Y. and S. Atobe. 1970. Phytosociological study of intertidal marine algae. I. Usujri Benten-Jima, Hokkaido. Bull. Fac. Fish. Hokkaido Univ. 21: 37-69.

Santelices, B. 1978. Multiple interaction of factors in the distribution of some Hawaiian Gelidiales (Rhodophyta) Pac. Sci. 32: 119-147.

Santelices, B. 1988. Synopsis of biological data on the seaweed genera Gelidium and Pterocladia (Rhodophyta) FAO Fish. Synop. 145: 55 pp.

Thomas, P. C., K. Rama Rao and K. Subbaramaiah 1975 a. Periodicity in growth and production of agar of
Gelidiella acerosa (Forssk.) Feldmann et Hamel. Indian J. Mar: Sci. 4: 210-212.

Thomas, P. C., K. Rama Rao and K. Subbaramaiah. $1975 \mathrm{~b}$. Changes in the natural growth of Gelidielle acerosa (Forssk.) Feldmann et Hamel in an exploited population. Bot. Mar. 18: 241-243.

Thomas, P. C., K. Subbaramaiah and E. R. R. Iyengar. 1978. Natural growth and agar content of Gelidiella acerosa (Forssk.) Feldmann et Hamel in an exploited population. Rev. Algol. N. S. 13: 341-347.

Valiela, I. 1984. Marine Ecological Processes. Springer-Verlag, New York. 547 pp.

Whyte, J. N. C. and J. R. Englar. 1980. Chemical composition and quality of agars in the morphotypes of Gracilaria from British Columbia. Bot. Mar. 23: 277-283.

Whyte, J. N. C., J. R. Englar, R. G. Saunders and J. C. Lindsay. 1981. Seasonal variations in the biomass, quantity and quality of agar, from the reproductive and vegetative stages of Gracilaria (verrucosa) type. Bot. Mar. 24: 493-501.

Wong, K. F. and J. S. Craigie. 1978. Sulphohydrolase activity and carrageenan biosynthesis in Chondrus crispus (Rhodophyceae). Plant Physiol. 61: 663-666.

Yamada, N. 1976. Current status and future prospects for harvesting and resource management of agarophytes in Japan. J. Fish. Res. Bd Can. 33: 1024-1030.

Yamada, N. and Y. Iwahashi. 1964. Studies on the manure for seaweeds. IV. On the manuring for yellowish Gelidium bed. Bull. Jap. Soc. Sci. Fish. 30: 986-992. 